\title{
ANALYSIS OF CONSEQUENCES OF USING GAS FUELS FOR RUNNING AUXILIARY SHIP BOILERS IN THE LIGHT OF CONTEMPORARY ENVIRONMENTAL PROTECTION REQUIREMENTS
}

\author{
Andrzej ADAMKIEWICZ \\ Maritime University of Szczecin \\ Marek BARTOSZEWSKI \\ SELFA GE S.A. \\ Martin KENDRA \\ University of Zilina
}

\begin{abstract}
:
The article justifies the application of gas fuels for supplying auxiliary ship boilers. It presents legal regulations on maritime environmental protection areas and their requirements which are in power. It shows the chronology of introduced limitations on sulphur and nitrogen dioxide emissions and thresholds of carbon dioxide emission reduction expressed by EEDI (Energy Efficiency Design Indicator) and EEOI (Energy Efficiency Operational Indicator). Ways to decrease the values of EEDI and EEOI in the ship energy effectiveness management have been shown. Consequences of replacing marine fuels with LNG for running auxiliary ship boilers have been considered thoroughly, taking into account ecological, constructional, operational, procedural and logistic limitations as well as economic consequences. The summary shows the influence of particular consequences of using LNG for running boilers on the methods of maintenance of auxiliary boilers.
\end{abstract}

Key words: auxiliary boilers, environmental protection, natural gas, marine fuel

\section{INTRODUCTION}

While mechanical power was getting more generally used for propelling vessels, an intensified process of polluting sea environment began. Industrial revolution of the 19th century led to the introduction of steam power both on cargo and military ships. Within years the steam power was replaced with motor one and coal with liquid fuels. An increase in the intensity of sailing added to the intensification of the environmental pollution process. In the second half of the twentieth century pollution of the atmosphere reached a level that required taking measures to stop the process. As a result, a number of regulations came into power to limit the emissions of harmful compounds and protection zones were designated in areas which were the most endangered by pollution. They were followed by changes in ship power technologies and first of all in the sources and methods of supplying power to engines and ship machines. On the one hand equipment for limiting emissions of harmful substances generated at burning the so-far used liquid marine fuels has been applied, while on the other hand it turned out that the simplest solution to the problem of environmental protection was the introduction of natural gas as the ship fuel.

\section{VALID LEGAL ACTS DETERMNINIG ENVIRONMENTAL PRO- TECTION REQUIREMENTS}

To limit the emissions of harmful substances into the atmosphere, a number of legal acts has been introduced throughout years. Their aim was to fulfill the requirements of maritime environment protection. The first regulations referring to that issue were comprised in the MARPOL $73 / 78$ convention, in the $\mathrm{VI}$ annex. That annex was added to the convention in 1997 and it came into power on 19th May 2006. This convention deals with limiting emissions of harmful substances (such as nitrogen oxides $\left(\mathrm{NO}_{\mathrm{x}}\right)$, sulphur oxides $\left(\mathrm{SO}_{\mathrm{x}}\right)$, solid particles $(\mathrm{PM})$ and volatile organic compounds (VOC)) to the environment [11].

Their acceptable emission is restricted throughout the introduction of sulphur content limit in the fuel. In the SECA - $\mathrm{SO}_{x}$ Emissions Control Areas, which include among others the Baltic Sea, since the 1st January 2015 the acceptable content has been $0.1 \%$. European Union countries operate according to IMO regulations, however the more restrictive regulations on sulphur oxide emissions in ports have been in power since an earlier date i.e. the $1^{\text {st }}$ January 2010 . They are obligatory in the port areas of the whole European Union and they enforce the use of fuels with less than $0.1 \%$ of sulphur in all sea-going and inland ships while in a port $[2,3]$.

These regulations were connected with the introduction of Emission Control Areas (ECA) by International Maritime Organization IMO. ECAs were designated in regions which were especially endangered by pollution caused by increased sailing. According to the regulations, ECA is the area where there are special obligatory requirements whose aim is to prevent, reduce and control pollution caused by $\mathrm{NO}_{\mathrm{x}}$, $\mathrm{SO}_{x}$ and greenhouse gases because of their negative influence on human health and natural environment [17, 19, 22]. The already existing and planned ECAs are shown in Fig 1. 


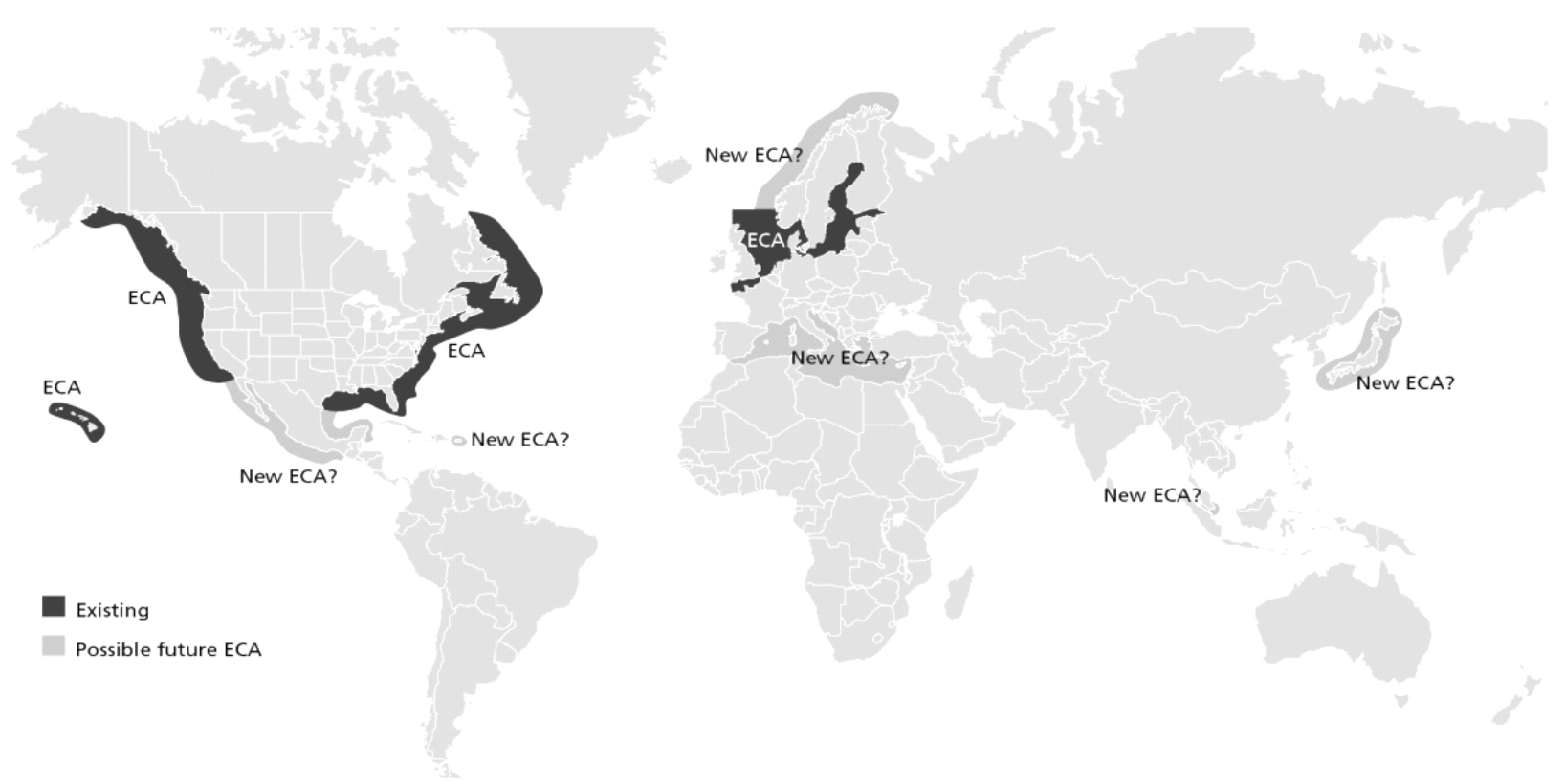

Fig. 1 Distribution of existing and planned ECAs

Source: [22].

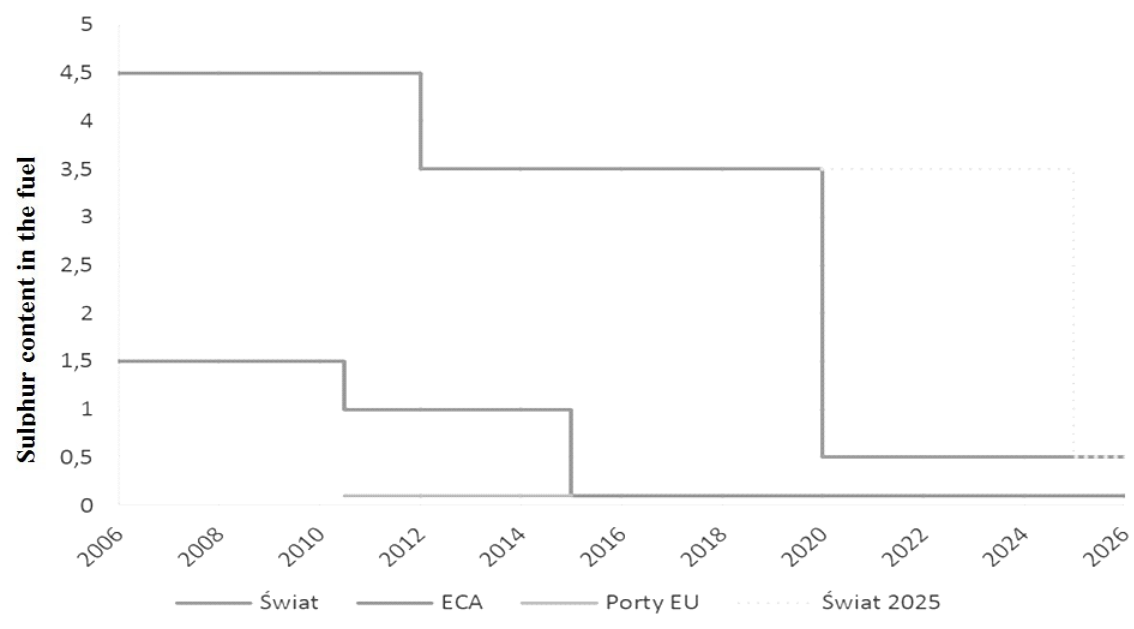

Fig. 2 Restrictions on sulphur content in marine fuels used within ECA

Source: [23].

Since the $1^{\text {st }}$ January 2015 within the ECA the acceptable level of sulphur in the fuel has been lowered to $0.1 \%$. IMO also accepts the use of technologies reducing the emissions of toxic compounds to the atmosphere giving similar results to the use of the fuel with reduced sulphur content. One of such technologies is applying liquefied natural gas as fuel. Installations of this type are built in such a way so that the gas could supply all the equipment, both the combustion engines and the boilers. Application of liquefied gas as fuel for supplying these facilities allows to meet the requirements of IMO for sulphur and nitrogen oxides and also for solid particles and greenhouse gases. Chronology of introducing more and more demanding requirements for sulphur content in the fuel within the ECA is shown in Fig. 2.

There are three steps in the reduction of nitrogen oxides emissions. At the moment, globally the second one is in power, whereas inside ECA the third one $[21,24]$. The acceptable levels of nitrogen oxides emissions into the atmosphere are shown in Fig. 3.

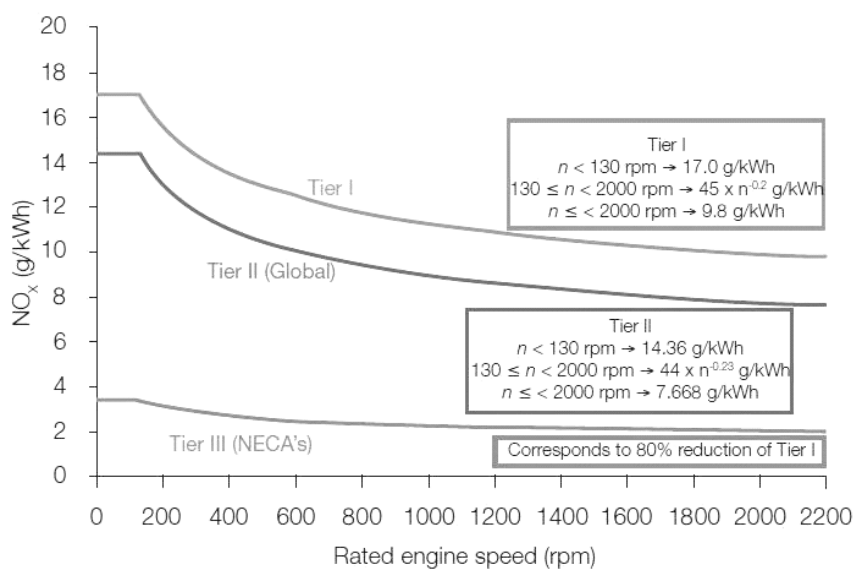

Fig. 3 Steps of reduction of nitrogen oxides emissions Source: $[1,9,10]$.

At present there are no legal limitations on $\mathrm{NO}_{\mathrm{x}}$ emissions from ship auxiliary boilers. Regulations set up by IMO refer only to exhaust gases from diesel engines, whereas 
boilers due to their slight part in the global emission were neglected in legal regulations.

In July 2011 on the basis of the MEP 203(62) resolution to the MARPOL convention, annex VI was enriched with an additional chapter - chapter 4, entitled "Regulations on energy efficiency for ships" in which the obligation of Energy Efficiency Design Index EEDI for new ships was determined - EEDI is calculated for a given type and size of ship. All new and earlier built ships are to have the Ship Energy Efficiency Management Plan SEEMP ensuring effective operation of the ship [1, 2, 3]. For current evaluation of ship transport effectiveness Energy Efficiency Operational Indicator is used on voluntary basis which is complementary to SEEMP $[1,3,9]$.

That issue is referred to by regulation 21 which applies to ships of 400GT and more. These regulations came into power on $1^{\text {st }}$ January 2013 whereas the MEPC XXX(63) resolution of March 2012 comprises recommendations for the regulations on ship energy efficiency $[21,24]$. Steps for carbon dioxide emission reductions represented by EEDI are shown in Fig. 4.

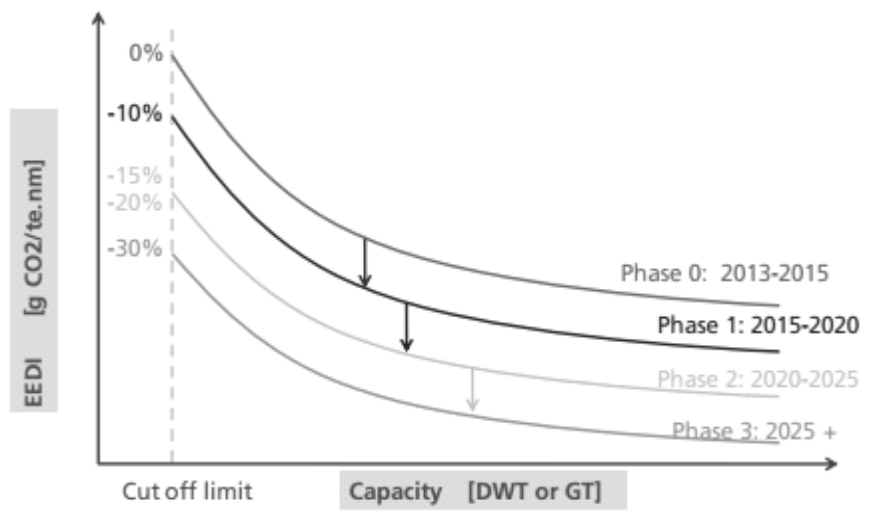

Fig. 4 Steps for carbon dioxide emission reductions Source: [20].

The possibility to use in protection areas ships whose power plants comprise dual fuel diesel engines which are supplied by different fuels including natural gas, created conditions for reaching bigger/better values of (Energy Efficiency Design Index) EEDI and (Energy Efficiency Operational Index) EEOI.

Those indexes together with the Ship Energy Efficiency Management Plan are tools for systematic control of the expected/designed and operational air pollution being the result of burning the fuel by the main and auxiliary engines, boilers and ship incinerator. Decreasing the value of EEDI and EEOI is possible throughout:

- limiting marine fuel consumption,

- using expensive fuels with low sulphur content,

- installing comparably expensive systems for exhaust gases purification from Sulphur, compounds, the so called scrubers,

- using exhaust waste heat (and energy from renewable sources),

- using LNG instead of fossil fuels by all facilities of the ship power system.

Using LNG as the only chemical energy source on a ship, guarantees meeting the requirements of emission controlled areas ECA $[1,3,9]$.

\section{CONSEQUENCES OF INTRODUCING LIQUIFIED NATURAL GAS FOR FEEDING AUXULIARY SHIP BOILERS}

Changes in legal regulations referring to acceptable emission levels of toxic products coming from burning of marine fuels were introduced due to the necessity of limiting the progressive degradation of the environment. Establishing Emissions Control Areas by the International Maritime Organization IMO and the requirements of limited emissions of toxic compounds in European Union harbours are at present the most important technological and logistic challenges for navigation. New limitations brought about changes in many branches of ship industry, even for those not directly connected with operation of machines emitting harmful substances.

\section{Ecological consequences}

Facing the more and more restrictive environmental protection requirements is quite a challenge for ship owners. Their basic problem is to maintain the acceptable emission limit for sulphur oxides $\mathrm{SO}_{\mathrm{x}}$ in the ship engine and ship boiler exhaust gases. In this respect, LNG is a good alternative for conventional liquid non-renewable fuels. The processes of natural gas liquefaction is connected with its very thorough purification, first of all from carbon dioxide and water. As a result of liquefaction very pure, odourless fuel is obtained which has not got toxic or corrosive properties. At the process of LNG burning production of sulphur oxides is significantly reduced (100\%), as well as of nitrogen oxides (about $85-90 \%$ ) and of carbon dioxide (about 15-25\%) in comparison to the emissions from Marine Diesel Oil (MDO). The level of burning product emissions for different methods of their reduction is shown in Fig. 5-8. These figures show the level of emissions, in the given order, of sulphur oxides, nitrogen oxides, carbon dioxide and solid particles for a ship typical for the Baltic Sea region [13].

\section{$\uparrow$ SOx Emissions (Tonnes/year)}

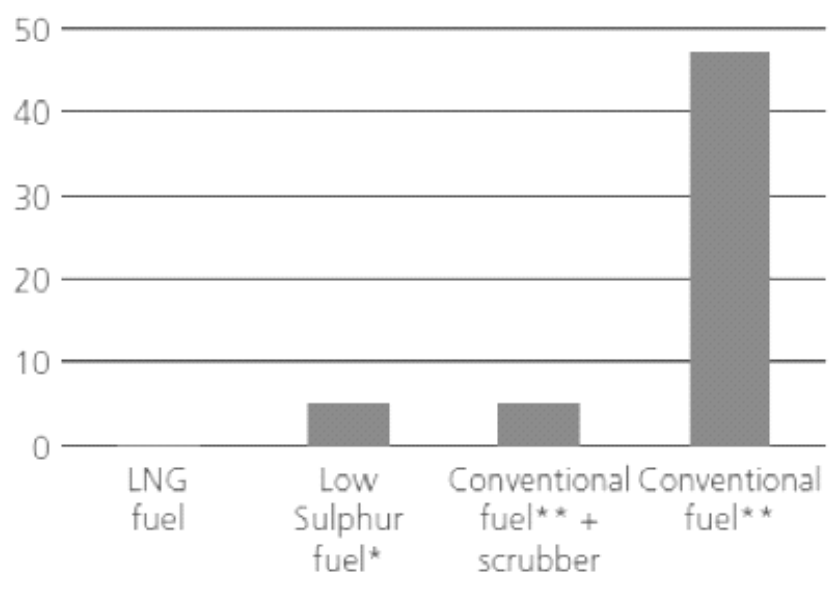

Fig. 5 Comparison of sulphur oxides emissions for different fuels/methods of their reduction Source: [13].

\section{Structural and operational consequences}

Switching from liquid to gas fuel brings about a number of technological consequences both for the construction of the ship and its installations, and its crew and their scope of duties. 


\section{$\uparrow \mathrm{NOx}$ Emissions (Tonnes/year)}

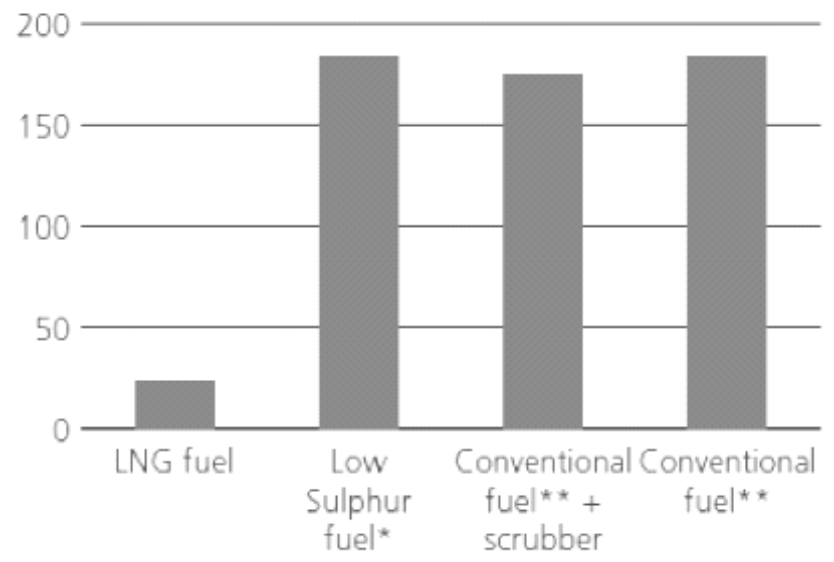

Fig. 6 Comparison of nitrogen oxides emissions for different fuels/methods of their reduction Source: [13].

\section{$\uparrow \mathrm{CO} 2$ Emissions (Tonnes/year)}

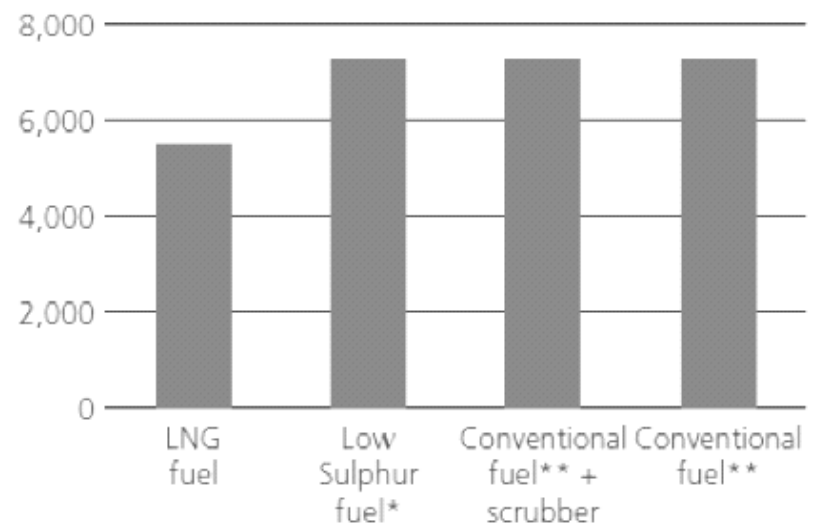

Fig. 7 Comparison of carbon dioxide emissions for different fuels/methods of their reduction Source: [13].

\section{$\uparrow$ Particle Emissions (Tonnes/year)}

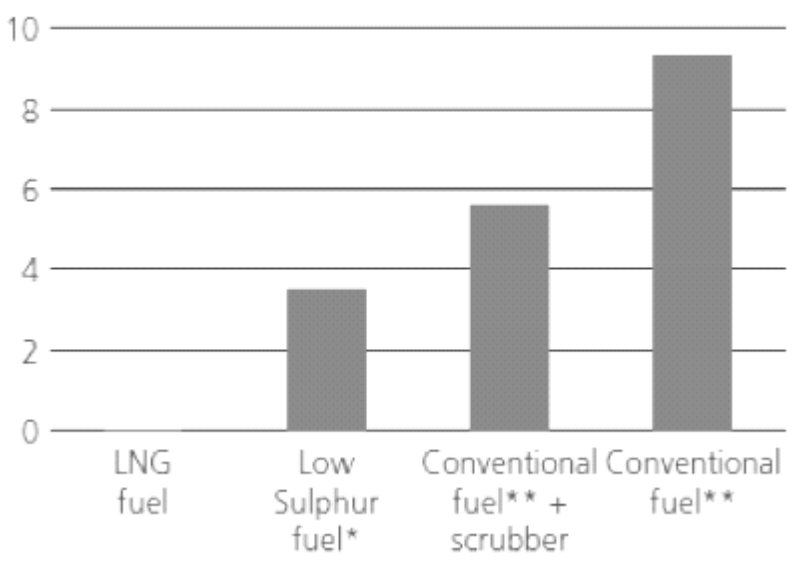

Fig. 8 Comparison of solid particle emissions for different fuels/ methods of their reduction Source: [13].

\section{STRUCTURAL CHANGES}

These changes come first of all from the necessity to install additional equipment (developed fuel installation and additional safety systems). It is connected not only with high investment costs but also with additional trainings of crews which are crucial for correct and safe operation of this equipment. The key element of LNG fuel installation is the cryogenic tank together with the installation for gas compression and evaporation. The construction of the cryogenic tank is shown in Fig. 9 [5].

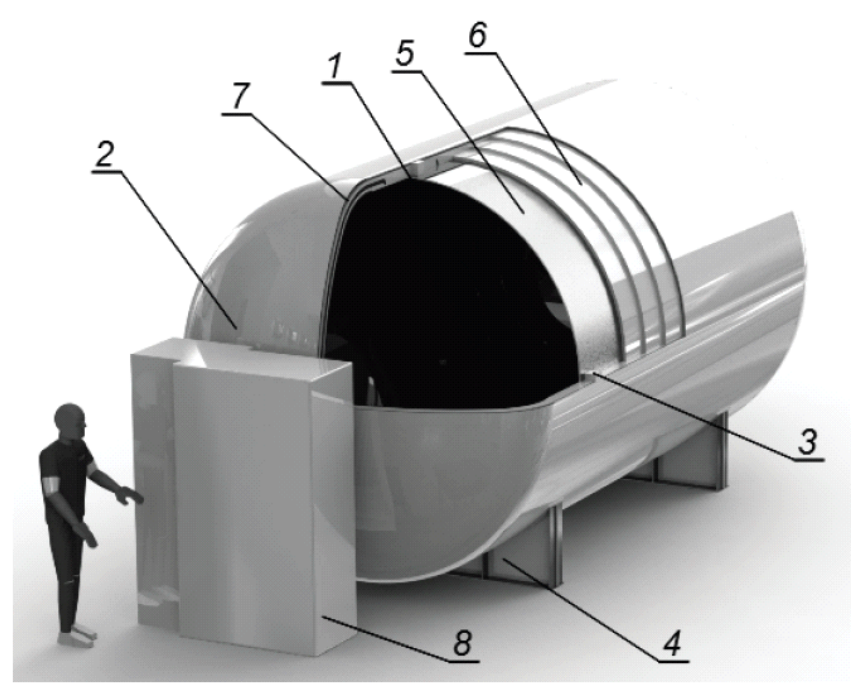

Fig. 9 Cryogenic tank construction

1 -inner tank; 2 - outer tank; 3 - inner supports; 4 - outer supports; 5 - insulation, 6 - protection from radiation, 7-vacuum layer; 8 -terminals Source: [5].

The diagram of the installation and the organisation of gas preparation installation vary depending on the type of LNG carrier, the type of its power plant and the way in which BOG is utilized. An example of such a diagram is shown in Fig. 10.

Process flow diagram

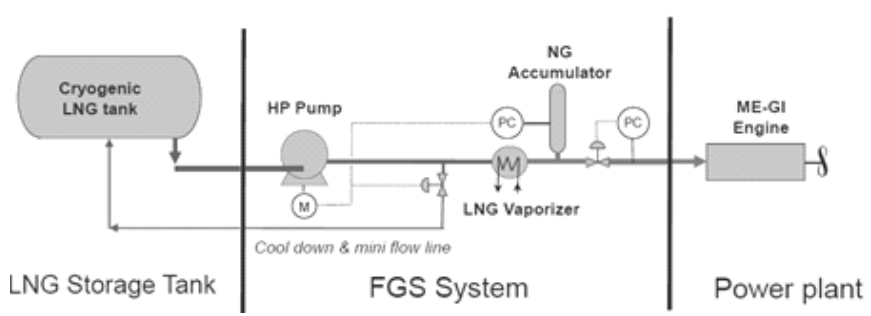

Fig. 10 A diagram of a chosen LNG installation Source: $[4,18]$.

All installations, however, posses key elements enabling realization of different procedures changing gas properties: compression and heating of the gas i.e in steam turbine power systems, apart from the basic boiler safety measures such as: control of water level in the boiler, anti-explosion precautions or control of fuel pressure and temperature it is also necessary to install additional safety protection dedicated to LNG installation. Depending on the construction of the installation for gas feeding like duel fuel diesel engines or duel fuel steam boilers the key issue is the location of the gas valve unit. It comprises valves responsible for delivering gas to the diesel engine or boiler or securing the installation in case of a gas leakage. The gas valve unit shown in Fig. 11 is shut down when gas is detected in the gas valve unit area, gas leakage inside the double pipes in the installation with double piping, or gas in the containers or in the machine room with a single piping or the loss of its ventilation (stoppage of one of the ventilators) $[6,11,16]$. 


\section{Operational changes}

The tank required for LNG is 1.6 times bigger in volume than the one for marine fuel (liquid) like Marine Diesel Oil (MDO) or Residual Fuel Oil (RFO) or Heavy Fuel Oil (HFO) to obtain the same amount of energy contained in compared fuels. Moreover, in the case of LNG additional place is needed for the installation of gas preparation [6]. Fig. 12 compares the volume of HFO to the total fuel volume, the tank and installation in the case of LNG.
Installation fed by LNG in comparison with the tanks and marine fuel installation occupies significantly more space and diminishes the space available for the cargo and enforces reorganization of ship space. Location of the tank on the ship also turns out to be a structurally complicated issue. It has to be placed at a certain distance from the ship's sides and bottom so that it would be protected in the case of a collision or getting into shoal. Requirements referring to LNG tank location, presented graphically in Fig. 13 are regulated by the International Gas Carrier Code (IGC) $[12,17]$.

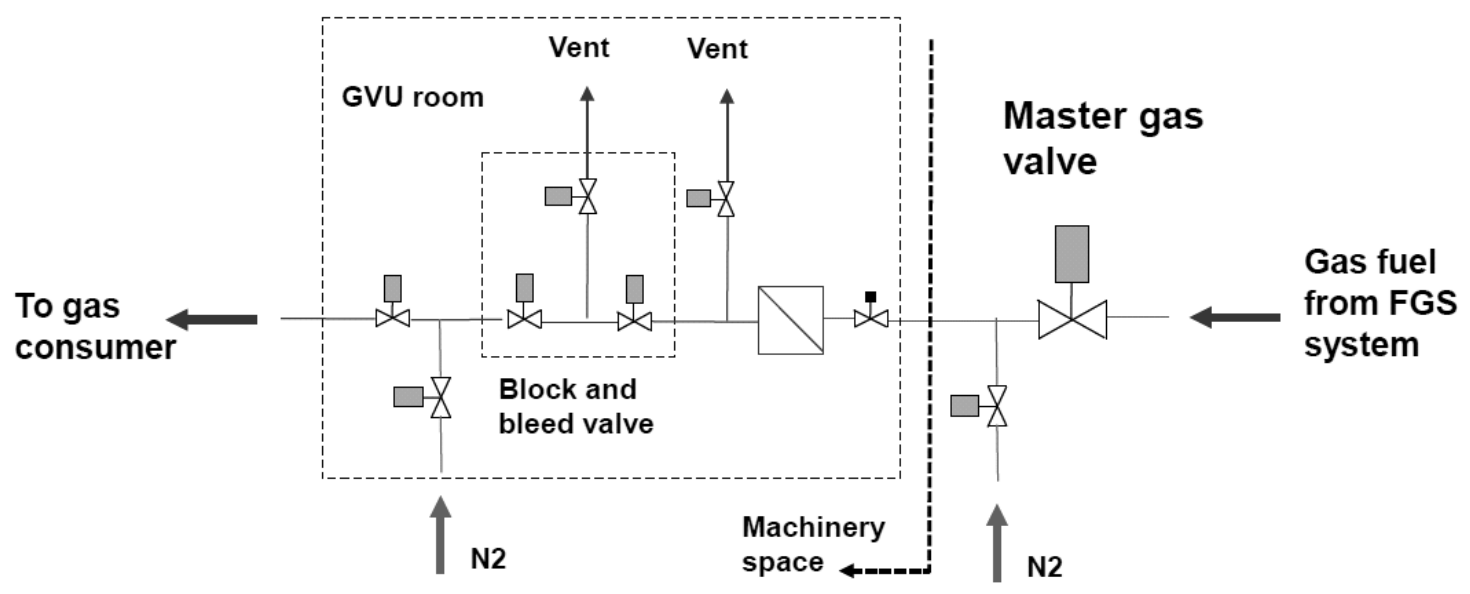

Fig. 11 A diagram of a gas valve unit Source: [6].

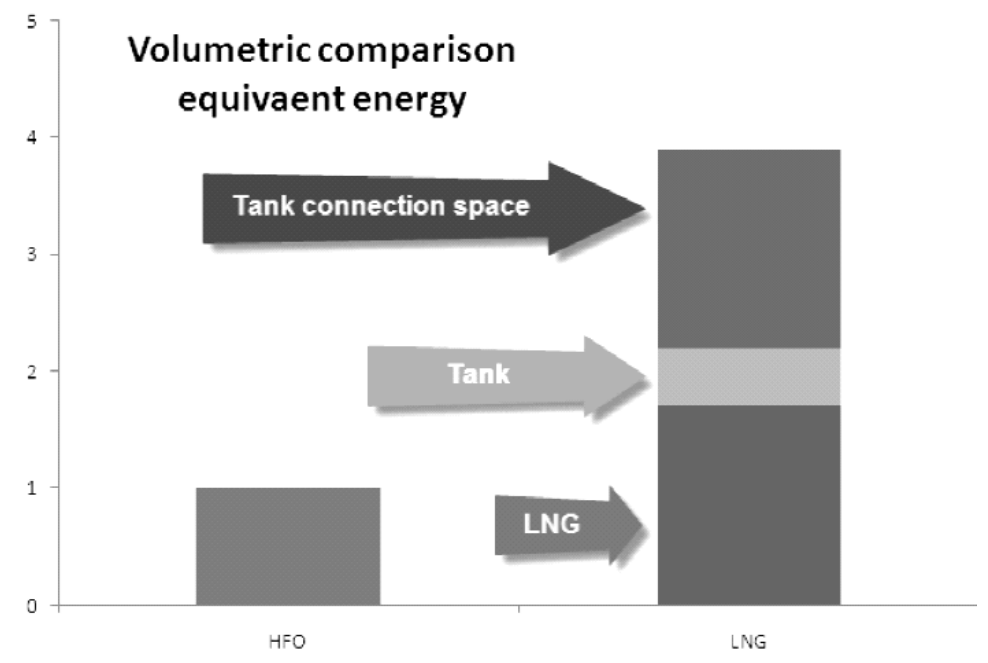

Fig. 12 Comparison of the volume occupied by the same energy value of marine fuels MDO and LNG Source: [6].
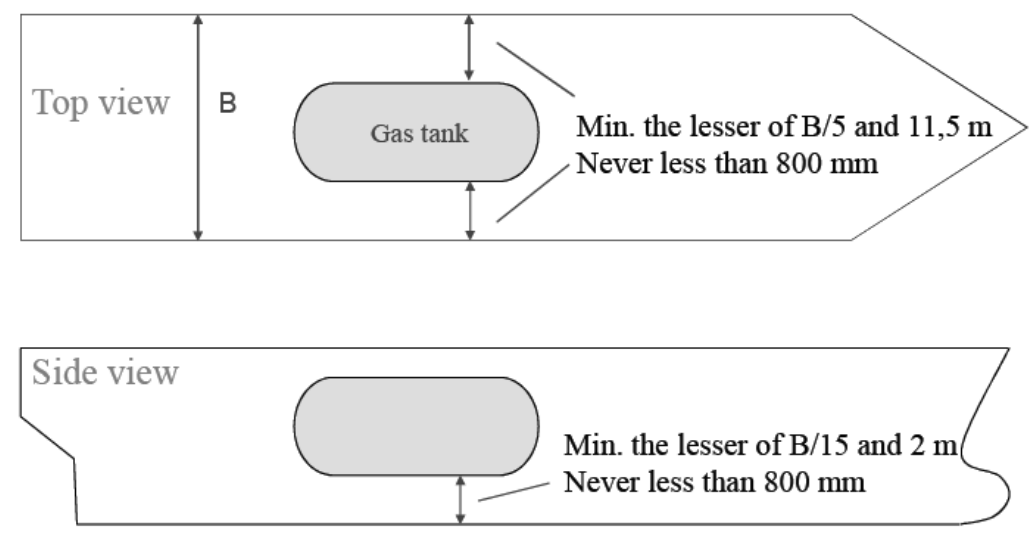
Locating gas tanks in compliance with the IGO directives is often very problematic, especially on ships which were not primarily designed to use LNG as fuel. Therefore, on many ships the gas tank is placed on the open board or in some cases they are mounted into the segment of the hull with installed LNG installation [14]. Equipping the LNG installation in special protective gear whose configuration is regulated by IGC is an indispensable element of construction modernization.

At the same time with all these changes it is necessary to modify the operational strategy of the ship power plant together with the changes in servicing procedures adjusting them to gas fuel. Frequently, there is no possibility of direct adaptation of already existing operational strategies of facilities due to continuous lack of precise experimental results of gas power plant operation. Only the experience from their prolong operation will enable obtaining knowledge and experience in operation of systems of this kind using control systems of the expert type.

\section{Economic consequences}

Fig. 14 shows the comparison of cost changes with time of available technologies of reducing emissions of toxic compounds to the atmosphere. The key criterion of choosing a technology to limit the emissions of toxic compounds to the atmosphere was the cost of fuel.

The diagram was prepared for a tanker of 50000 DWT servicing the route Rotterdam-New York-Houston. The ship remains within the ECA area for $30 \%$ of its time. The choice of emission reduction method was based on the expected fuel cost $[7,15]$.

The consequences of using liquefied gas to run a ship comprise both the investment and operational costs, where investment costs are the consequence of purchasing the LNG tank, LNG installation, modernization of equipment for gas burning, modification of equipment in the ship engine room, determination of danger zones and thorough separation of gas burning equipment from the area of the ship power plant [14]. Undoubtedly the use of LNG is the most advantageous, however it strongly depends on its price.

\section{Other consequences}

Application of LNG as fuel also generates changes in the procedures of ship operation, logistic limitations and among others economic consequences.

\section{CHANGES IN SHIP PROCEDURES}

A consequence of switching to LNG as fuel is also the change of fuel bunkering procedure. Due to physicochemical properties of natural gas, it requires additional activities in in the process of bunkering as well as maintaining special precautions. The biggest problem at bunkering is utilizing the naturally evaporating gas. To fill the space after the pumped out gas one of two possibilities has to be used. The first of them is to direct the evaporated gas through a second bunkering hose back to the ship bunker tank, the second one is to use a vaporizer on the bunkering ship to which a part of the liquid cargo is directed, which is later evaporated and directed to the tank. In the second method the bunkered ship uses a liquefying installation so that the excess of evaporated gas could be condensed and pumped to the tank. The first method is much easier, however it decreases the amount of carried cargo as part of the cargo goes back to the tank. The second method requires mounting a vaporizer and a complicated installation for gas re-liquefaction $[7,8]$. Diagrams of both methods are presented in Fig. 15.

The procedure of pumping the bunkered fuel itself gets changed as well. At first bunkering hoses have to be filled with a neutral gas so as to exclude the possibility of contact between atmospheric air and natural gas and thus the possibility of an explosive mixture. Subsequently bunkering hoses are gradually cooled down with the evaporated gas in order to prepare the installation for pumping the liquefied gas. After such preparations, the process of pumping of the condensed gas may begin. When the operation of pumping is finished, the liquefied gas from the bunkering hoses has to be dislodged by the evaporated gas and later the natural gas vapors are dislodged by neutral gas. After completing the operations described above, bunkering installation can be disconnected.

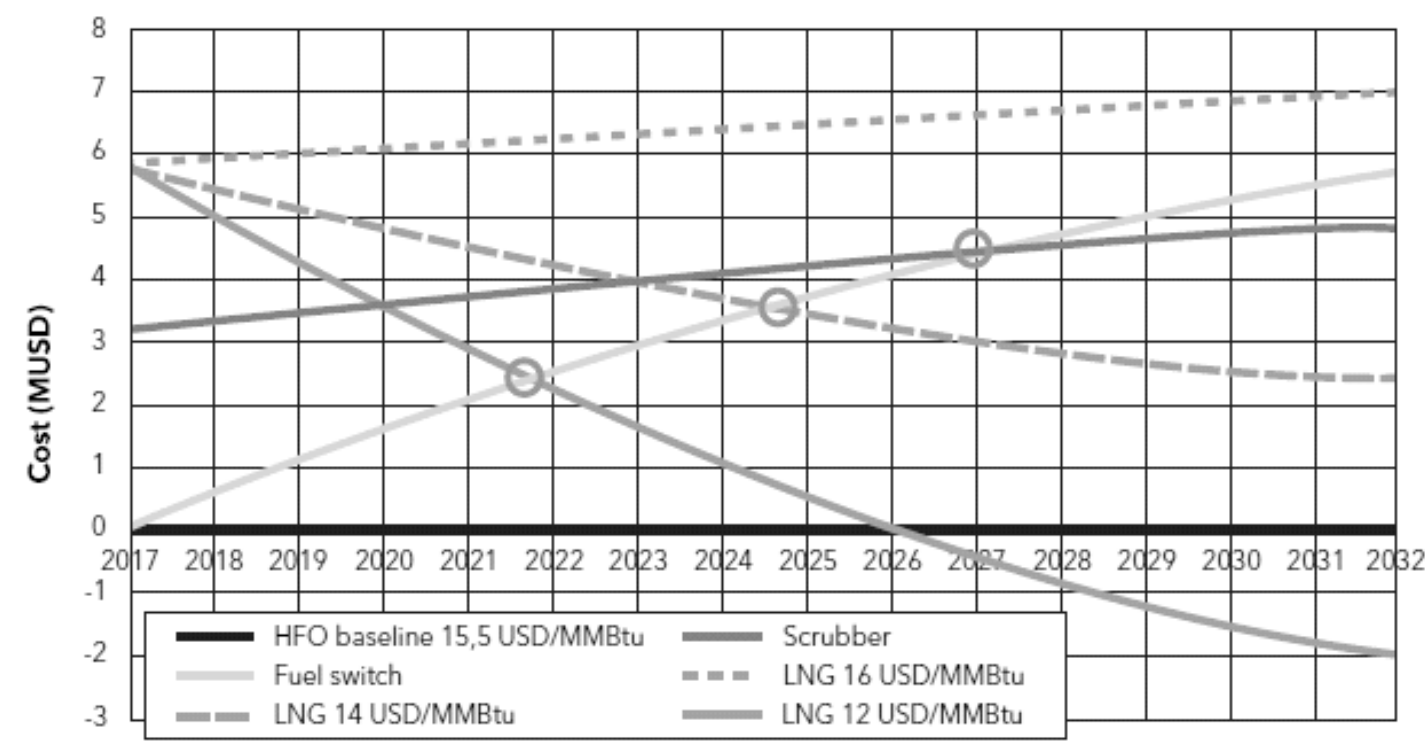

Payback time and value of the investment over the lifetime of the ship, taking into account all relevant options for future emission compliance 


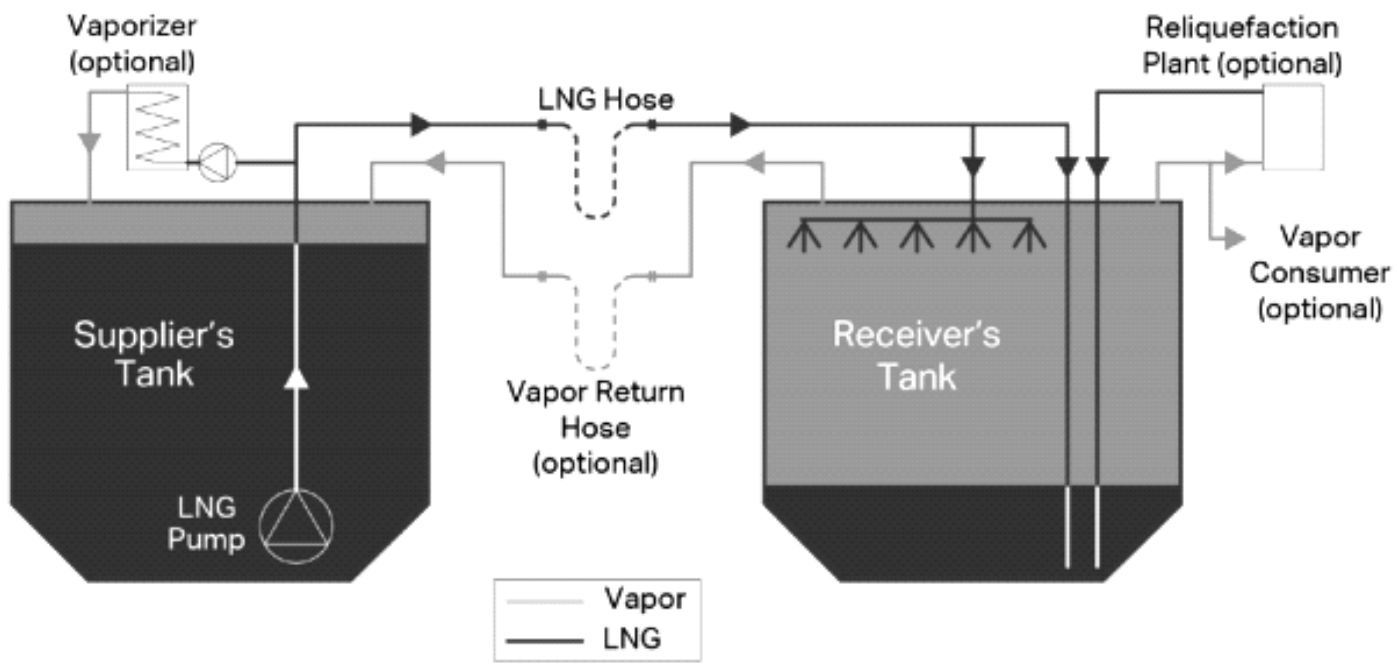

Fig. 15 Methods of attaching bunkering hoses Source: [7].

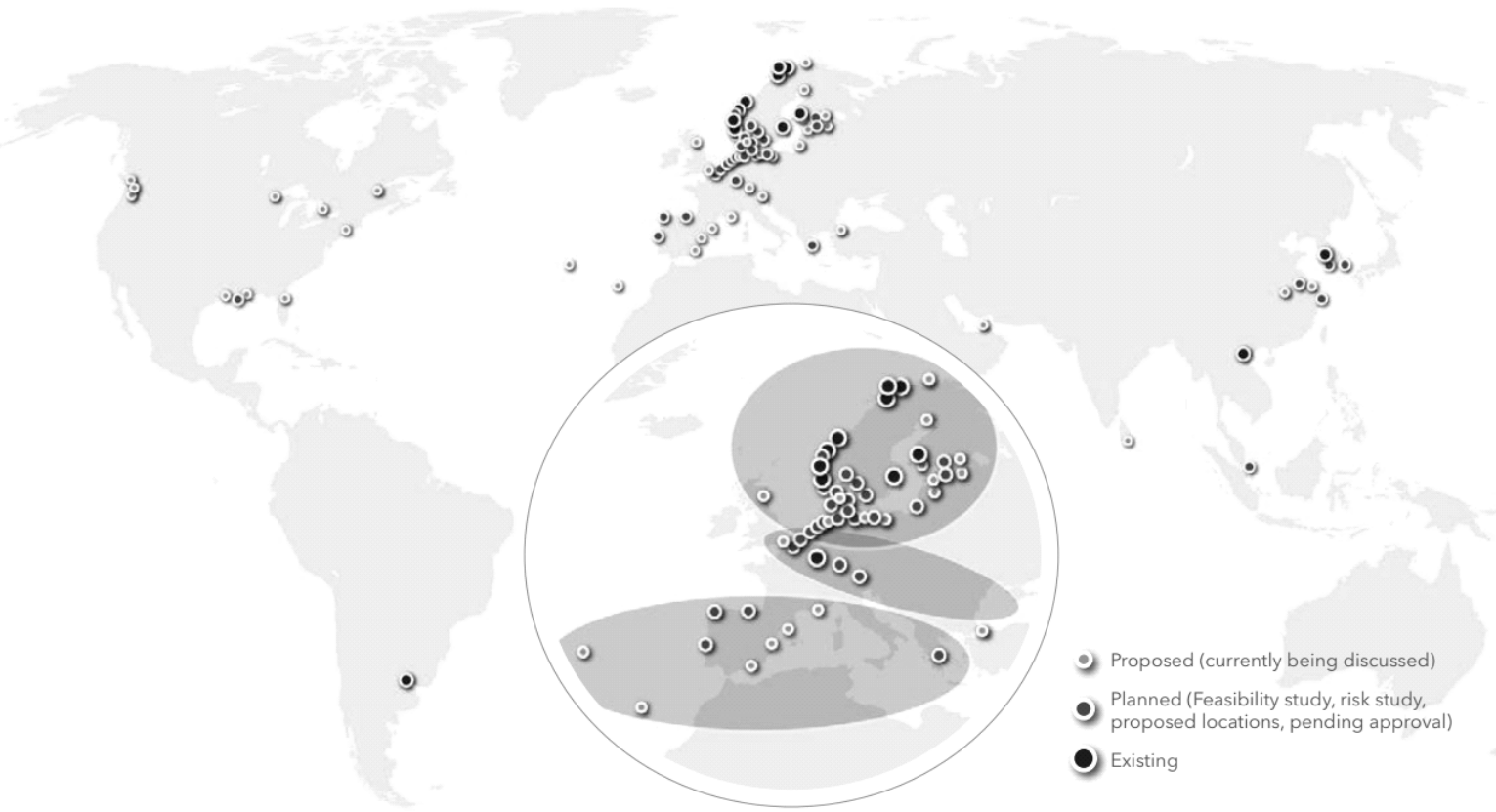

Fig. 16 Distribution of LNG bunkering infrastructure LNG Source: [14].

Changes in procedures which are the result of different physicochemical properties of gas fuels determine the necessity of supplementing port installations with elements adjusted to liquefied gas transportation.

\section{Logistic limitations}

Because of growing demand for natural gas, the main task that faces ship industry is developing the necessary infrastructure for LNG bunkering. At present Europe is the leader in this field with the biggest number of LNG bunkering terminals that has already been built and has been planned to be built $[14,15]$. Distribution of the built and planned terminals is shown in Fig. 16. Current distribution of LNG bunkering terminals determines the area where ships running on this fuel can operate and it is the key factor in logistic planning of routs for such ships.

\section{SUMMARY}

Using LNG for running facilities such as diesel engines and boilers is one of the solutions which allows to meet the restrictive IMO regulations regarding environmental protection. Choosing LNG as a way to reduce toxic compound emissions requires substantial investments. However, this method pays back faster than any other. LNG application apart from economic consequences also brings about operational consequences. Installations of this type contain a number of additional facilities which have to be applied in the power plant and must be operated and serviced by the ship's crew. Procedures of operation and operational strategies also have to change. In the case of using LNG as fuel, its accessibility can also be problematic. At present the number of ports offering LNG is highly limited which is a decisive factor in the choice of route and area of voyages. Also the procedure of LNG bunkering is different from that which is used for liquid marine fuels. 


\section{REFERENCES}

[1] A. Adamkiewicz and M. Przybyła. „Wpływ rodzaju paliwa spalanego w okrętowych silnikach dwupaliwowych na wielkość powierzchni wymiany ciepła odzyskaniowego podgrzewacza wody", in VI Konferencja Naukowo-Techniczna Energetyka Gazowa 2016, Zawiercie, Poland, 2016, pp. 107-120.

[2] A. Adamkiewicz and J.P. Cydejko. „Analiza układów napędowych zbiornikowców LNG w aspekcie spełnienia wymagań strefy kontroli emisji spalin", in Rynek Energii, vol. 118(3), 2015, pp. 80-86.

[3] A. Adamkiewicz and W. Zeńczak. „LNG as an Ecological Fuel For Sea-Going Vessels", in Symposium Nutzung Regenerativer Energiequellen Und Wasserstofftechnik, Stralsund, Germany, 2013, pp. 8-13.

[4] M. Bartoszewski. „Analiza konsekwencji wprowadzenia paliw gazowych do opalania okrętowych kotłów pomocniczych w świetle współczesnych wymagań ochrony środowiska", M.S. thesis, Faculty of Marine Engineering, Maritime University of Szczecin, Szczecin, Poland, 2015.

[5] E. Lisowski and W. Czyżycki. „Transport and storage of LNG in container tanks", in Journal of KONES, vol. 18 (3), 2011, pp. 193-201.

[6] LNG Fuel Systems: Certification \& Approval, ABS, 2012.

[7] LNG Bunkering: Technical and Operational Advisory, ABS.

[8] LNG Ship to Ship bunkering procedure, Swedish Marine Technology Forum.

[9] MARPOL How To Do It 2013 Edition, International Maritime Organization, London, 2013.

[10] „MARPOL Annex VI: Regulations for the Prevention of Air Pollution from Ships and NOx", in Technical Code 2008, International Maritime Organization, 2009.

dr hab. inż. Andrzej Adamkiewicz, prof. AM

Maritime University of Szczecin

Faculty of Mechanical Engineering

Wały Chrobrego 1-2, 70-500 Szczecin, POLAND

e-mail: a.adamkiewicz@am.szczecin.pl

mgr inż. Marek Bartoszewski

SELFA GE S.A.

ul. Bieszczadzka 14, 71-042 Szczecin, POLAND

e-mail: butchbutchi@gmail.com

doc. Ing. Martin Kendra, PhD

University of Zilina, Department of Railway Transport

Univerzitná 8215/1, 01026 Žilina, SLOVAKIA

e-mail: martin.kendra@fpedas.uniza.sk
[11] Międzynarodowy Kodeks Budowy i Wyposażenia Statków przewożq̨cych skroplone gazy luzem (Kodeks IGC), Polski Rejestr Statków, Gdańsk, 2001.

[12] Gas as a ship fuel. Safety rules and regulations, status of IGF code, DNV GL, 2013.

[13] LNG - an energy source and a new fuel for shipping in Northern Europe, Baltic Ports Organization's LNG Seminar, DNV GL, 2011.

[14] LNG as Ship Fuel, DNV GL, 2014.

[15] LNG: Straight Ahead to safe LNG bunker supply, InFocus, GL, 2013.

[16] LNG Fuel Systems Design \& Requirements, Hellenic Register of Shipping, 2014.

[17] Outline of Liquified Gas Carriers, Nippon Kaiji Kyokai, 2002.

[18] Shipping 2020. Technology investments in the new market reality, DNV GL, 2013.

[19] Process flow diagram, [Online]. Available: http:// www.Ingbunkering.org/lng/sites/default/files/ processflow2_0.png

[20] T. Sinha. EEDI - The Future of Green Shipping, [Online]. Available: http:// Ishipdesign.blogspot.com/2014/03/eedi-future-ofgreen-shipping.html

[21] International Maritime Organization [Online]. Available: http://www.imo.org

[22] 10 Reasons Why Ship Operators Should be Nervous About the 2015 ECA Regulations, [Online]. Available: http://maritimecyprus.com/2014/11/19/10-reasonswhy-ship-operators-should-be-nervous-about-the2015-eca-regulations/

[23] International: IMO Marine Engine Regulations, [Online]. Available: http://www.dieselnet.com/ standards/inter/imo.php

[24] Polski Rejestr Statków [Online]. Available: http:// www.prs.pl
Artykuł w polskiej wersji językowej dostępny na stronie internetowej czasopisma.
The article in Polish language version available on the website of the journal 